\title{
Wide field scanning by optical fluorescence of oral squamous cell carcinoma (SCC): case report
}

\author{
Fotoevidenciação de campo amplo por fluorescência óptica de carcinoma \\ de células escamosas (CEC) oral: estudo de casos
}

\author{
Ismael Lucas PINTO1 iD https://orcid.org/0000-0002-9441-1091 \\ Jairo G. CARLOS² iD https://orcid.org/0000-0001-5968-0221 \\ Ana Paula OLIVEIRA DE ARAÚJO33 iD https://orcid.org/0000-0002-3150-9737 \\ Clóvis Milton Duval WANNMACHER ${ }^{4}$ iD https://orcid.org/0000-0002-7826-8416
}

\begin{abstract}
Optical fluorescence detection aims to identify precursor lesions, little noticeable to the human eye, and oral cancer. Squamous cell carcinoma or spinocellular carcinoma is a malignant neoplasm that affects the mouth more. In this article, two clinical cases are analyzed, treated with the use of two types of equipment, namely: the photoevidenciation by optical fluorescence of light-emitting violet wavelength of $405 \mathrm{~nm}$, power of $100 \mathrm{~mW}$, which is luminous radiation, not lonizing and in the adjuvant treatment, we used lowpower laser therapy, power $100 \mathrm{~mW}$, with two wavelengths of $808 \mathrm{~nm}$ infrared, for pain relief, and the red 660nm, for oral mucositis. In Photodynamic therapy, the Photosensitizing Chimiolux ${ }^{\circledast}$ (methylene blue) was used to control Candida albicans. From these cases, we discuss how a more assertive diagnostic hypothesis can save a life and save time, resources, and efforts for the correct diagnosis of the pathology compared to a biopsy and histopathology negative for neoplasia. We conclude that optical fluorescence has excellent social relevance due to its potential to help the professional not specialized in the establishment of early diagnosis of oral cancer. Early diagnosis improves the rates of death caused by this carcinoma, which would extend the post-diagnosis survival and decrease the financial and emotional costs for the patient and family.
\end{abstract}

Indexing terms: Fluorescence. Laser therapy. Squamous cell carcinoma.

\section{RESUMO}

A detecção óptica por fluorescência visa identificar lesões precursoras, pouco perceptíveis ao olho humano, e do câncer oral. O carcinoma de células escamosas ou carcinoma espinocelular (CEC), é a denominação de uma neoplasia maligna que acomete mais a boca. Neste artigo, são analisados dois casos clínicos, tratados com a utilização de dois equipamentos, a saber: o de fotoevidenciação por fluorescência óptica de emissão de luz violeta de comprimento de onda de 405nm, potência de 100mW, que é radiação luminosa não ionizante; e no tratamento coadjuvante, utilizou-se a laserterapia de baixa potência, potência 100mW, com dois comprimentos de onda de infravermelho $808 \mathrm{~nm}$, para alivio de dor, e o vermelho 660nm, para as mucosites orais. Na terapia fotodinâmica, empregou-se

\section{$\because \operatorname{rr}$}

${ }^{1}$ Conselho Nacional de Desenvolvimento Científico e Tecnológico (CNPq). SHIS QI 1, Conjunto B, Bloco B, 71605-002, Lago Sul, Brasília, DF, Brasil. Correspondence to: IL PINTO. E-mail: <ismael.pinto@cnpq.br>.

2 Instituto Federal de Santa Catarina, Faculdade de Engenharia Mecânica. Xanxerê, SC, Brasil.

3 Universidade Católica de Brasília. Brasília, DF, Brasil.

${ }^{4}$ Universidade Federal do Rio Grande do Sul, Instituto de Ciências Básicas da Saúde, Departamento de Bioquímica. Porto Alegre, RS, Brasil.

$\boldsymbol{\nabla} \mathbf{v} \boldsymbol{V}$

How to cite this article

Pinto IL, Carlos JG, Araújo APO, Wannmacher CMD. Wide field scanning by optical fluorescence of oral squamous cell carcinoma (SCC): case report. RGO, Rev Gaúch Odontol. 2021;69:e20210028. http://dx.doi.org/10.1590/1981-86372021002820190139 
o fotossensibilizador Chimiolux® (azul de metileno) para controle de Candida albicans. A partir desses casos, discutimos como uma hipótese diagnóstica mais assertiva pode salvar uma vida e poupar tempo, recursos e esforços para o correto diagnóstico da patologia se comparado a uma biópsia e histopatológico negativo para neoplasia. Por fim, concluímos que a fluorescência óptica tem grande relevância social devido a seu potencial de auxiliar o profissional não especialista no estabelecimento de um diagnóstico precoce do câncer oral, melhorando os índices de óbito causados por esse carcinoma, o que estenderia a sobrevida pós-diagnóstico e diminuiria os custos financeiros e emocionais do paciente e familiares.

Termos de indexação: Fluorescência. Terapia a laser. Carcinoma espinocelular.

\section{INTRODUCTION}

Historically, in Brazil, oral cancer has been detected belatedly due to numerous factors. One of the factors related to this study is the performance of the clinical visual examination and palpation, using white illumination light. In suspected cases, the biopsy is performed. Nowadays, it has been sought to include technological resources to assist in photodetection using the emission of violet light for higher contrast and evidence of the first aspects of Potentially Malignant Injuries or cases of early diagnosis of cancer. In this article, we present two clinical cases of oral cancer (squamous cell carcinoma - SCC or spinocellular carcinoma - SCC), to show how the technological support of optical fluorescence can assist in the early clinical diagnosis of this pathology, even if performed by professionals nonspecialists in stomatology/pathology, without trained eyes and without daily experience in examining oral lesions. This technology favors that the clinician establishes a more certain diagnostic hypothesis, providing a greater engagement of the professional in the prophylactic approach and a more global and efficient anamnesis with quality of life for the patient. The treatment is performed by Low Level Laser Therapy (LLLT) to control pain, and by photobiomodulation (PBM- Photobiomodulation) as anti-inflammatory effect, helping to healing the process. For microbial reduction, photodynamic therapy (aPDT- antimicrobial Photodynamic Therapy) is used with the associated use of LASER with the resonant photosensitizer. This association, which absorbs the emitted light and promotes the diminution of Candida albicans, which, although native to the oral cavity, is opportunistic, colonizing the sites opened by ulcers of oral mucositis, caused by chemotherapy/radiation therapy used to combat malignant neoplasia. With this set of techniques, it is possible to provide post-diagnostic survival with better health for the patient.

\section{Epidemiology}

It is known that the term cancer refers to the grouping of diseases of approximately 200 similar pathologies, which have in common a rapid and disordered growth of their cells, invading adjacent tissues and organs, which can spread to other parts of the body, called metastases, and tend to be very aggressive and uncontrollable, forming malignant tumors or neoplasms.

The World Health Organization (WHO) classifies cancer as a public health issue, a predictable chronic disease. It estimates that prevention can help reduce cancer incidence by up to $25 \%$ by the year 2025 , recommending technological incorporation in the viewing of reducing the impact on the population. Mouth cancer is among the fifth most incident among men, and $70 \%$ of cases are diagnosed in individuals over the age of 50 years. The estimative of new cases of mouth cancer for 2018, according to the National Cancer Institute (INCA), is $14,700,11,200$ men, and 3,500 women [1, 2]. Based on the Mortality Information System of the Ministry of Health (SIM/MS), the most incident types of cancer in the world were: lung (1.8 million), breast (1.7 million), intestine (1.4 million), and prostate (1.1 million). In men, the most frequent were lung $(16.7 \%)$, prostate $(15.0 \%)$, intestine $(10.0 \%)$, stomach $(8.5 \%)$ and liver $(7.5 \%)$. In women, the highest frequencies of cancer were those that affected the breast $(25.2 \%)$, intestine $(9.2 \%)$, lung $(8.7 \%)$, cervix (7.9\%), and stomach (4.8\%) [3].

According to Globocan/larc, in 2012, 300,373 new cases of the lip and oral cavity cancers (COO-C08) were estimated worldwide. This estimate excluded amygdala and oropharynx cancers (C09-C 10). Cancer type C00-C08 occupies the fifteenth(15a) position among all cancers, of which more than half affect men (198,975 new cases). Regarding mortality, mouth cancer was responsible for 145,353 deaths worldwide in 2012. This value corresponds to an estimated risk of 2.1 deaths per 100,000 inhabitants, representing a global public health problem [3].

In Brazil, 2018, INCA data show that approximately 300,000 new cases of neoplasms emerged. There is a prevalence of prostate cancer in men $(68,220,000$ cases), which corresponds to an estimated risk of 62.12 new cases 
per 100,000 men and breast cancer in women (59,700,000 cases), which corresponds to an estimated risk of 56.33 new cases per 100,000 million. It is worth mentioning that $90 \%$ of these cases will appear in smokers. For comparison, deaths from oral cavity cancer in men were 4,672 and 1,226 in women [1].

These data show that, without considering nonmelanoma skin tumors, the first incidence is prostate cancer, which corresponds to $31.7 \%$ of cases. The second most incident type is trachea, bronchial, and lung cancer $(18,740$ or $8.7 \%)$. The 3 rd type is intestinal, and rectum colon $(17,380$ or $8.1 \%)$, and the 4 th is the stomach $(13,540$ or $6.3 \%)$. Finally, the 5 th type of highest incidence is the one that affects the oral cavity $(11,200$ or $5.2 \%)$, which corresponds to an estimated risk of 10.86 new cases per 100,000 men [1].

In women, without considering non-melanoma skin tumors, breast cancer is the most prevalent and corresponds to $29.5 \%$. The 2 nd in prevalence is bowel and rectum colon cancer $(18,980$ or $9.4 \%)$. The 3 rd is the cervix $(16,370$ or $8.1 \%)$, and the 4 th is the trachea, bronchus, and lung cancer $(12,530$ or $6.2 \%)$. The 5 th most incident type is the thyroid gland $(8,040$ or $4 \%)$. The 6 th is the stomach $(7,750$ or $93.8 \%)$. Other examples follow, and cancer in the oral cavity is the 12 th in incidence $(3,500$ or $1.7 \%$ ) and corresponds to an estimated risk of 3.28 new cases per 100,000 women ([1]).

The most common cancer sites in the mouth are tongue (26\%) and lip (23\%), mainly the lower part. Another $16 \%$ occurs on the floor of the mouth and $11 \%$ in the smaller salivary glands. The rest happens in the gums and other sites.

Dentists make the most diagnosis, but only $20 \%$ of cases are diagnosed in early stages, so $80 \%$ are advanced cases, more difficult to treat [1].

The data cited in Brazil show a higher prevalence of oral cancer in men $(11,200,000$ new cases) than in women $(3,500,000$ new cases). This different prevalence may be due to a higher smoking habit, alcohol consumption, and human papillomavirus (HPV) infections (Human Papillomavirus) since they imply a higher risk for the development of cancer [1].

In Brazil, cancer is worse because treatment usually happens in its later stages since most tumors are diagnosed in very advanced stages. Because of it, the possibility of treatment is reduced, and the consumption of public resources for disease control actions increases, varying according to clinical, genetic, socioeconomic, and environmental factors. Another aspect is that, in the early stages, tumors of the oral cavity are usually asymptomatic and may disguise the common benign conditions of the mouth $[4,5]$.

Literature studies show that alcoholism, smoking, and HPV infections are the main risk factors for the onset of oral cancer. These factors are probably the main responsible for the incidence of two-thirds of cases in males $[4,6,7]$.

Squamous cell carcinoma (SCC), also known as Spinocellular carcinoma - SCC, is the name of a malignant neoplasm that affects the upper aerodigestive tract (UADT). In general, it develops from progression and staging, initially by reddish-stained erythema, evolving to epithelial hyperplasia with hardened edges, moving to an in situ carcinoma, and then to the invasive form.

The SCC preferentially affects men over 50 years of age, with few clinical cases described in the literature of female patients [6].

Generally, malignant tumors that affect nonsmoking and non-alcoholic patients occur at later ages, and the disease tends to be quite aggressive, which intensifies oral health care [7].

The significant relevance to preventing oral cancer is the high incidence and mortality, culminating in the enactment of Law $N^{\circ}$. 13,230 / 2015, establishing the National Week for the Prevention of Oral Cancer in Brazil. These are educational campaigns to emphasize appropriate attitudes in oral care, seeking to prevent, guide and remember the risks, the campaign occurs throughout the first week of November of every year.

\section{CASE REPORT}

This manuscript is a clinical case study that compares the early diagnosis of oral cancer with the discovery of late-stage cancer. Two patients were selected for this purpose. The first patient showed a lesion in the oral cavity. Photoevidenciation was performed, detecting the disease in the early phase. In the second case, a patient has already had SCC in the final stage of the disease. This find corroborates the recurring problem of late disease detection that can be avoided.

The Semiology of the Clinical Diagnosis of Oral Cancer is based on a detailed assessment of the signs and symptoms that will form the dental record. 
The signs are objective clinical data while the symptoms are subjective, reported by the patient, such as hallucinations, dizziness, anxiety, pain, stress, among others. However, the professional must quantify and qualify this information.

In the anamnesis, the patient's identification, the main complaint, the past and current history of the diseases, hereditary antecedents, habits, and psychological aspects are collected. The extraoral physical examination aims to evaluate the Stomatognathic System in search of abnormalities of the facial physical aspect: facial skin, nose, phonation, palpation of the TMJs (temporomandibular joint), lymph nodes, respiratory rate, temperature, and blood pressure. The intraoral physical examination consists of a professional clinical examination or a self-examination, looking for possible changes in the mucous membranes, gums, tongue, hard and soft palate floor, teeth, and dental arches.

In the case of suspicion, a professional should be sought to resolve doubts. Physical or chemical means can be used to increase the accuracy of the diagnostic analysis. Magnifying glasses, stethoscope, light, chemical dyes, or microbial biofilm enhance the lesions, allowing a better assessment of primary oral lesions or oral manifestations of systemic diseases.

To improve the diagnosis, the in vivo staining technique for neoplastic lesions, using $1 \%$ toluidine blue, a metachromatic cationic dye from the thiazine group may be performed. An excellent microbial biofilm marker for oral neoplasms at low cost may be used. The biofilm is a biomarker used in children's motivational campaigns showing areas of poor oral hygiene, and it also serves to stain HPV. In oral malignant lesions, it enhances the lesions, facilitating the demarcation, serving as a guide to the surgeon in the excision of the lesion and the immediate histopathology, to ensure the total removal of the injured area [8].

Wood's lamp (WL) is an emitter of ultraviolet and violet light. However, the most significant emission occurs in the spectrum invisible to the human eye, which can reflect light in the visible spectrum in non-melanoma skin cancer. The LW can be found in various sizes, powers, and or be attached to a transparent magnifying glass [9].

This low-cost technique, a sulfur lamp designed by engineer Michael Ury, physicist Charles Wood and his colleagues in 1990, is the most suitable for identifying non-melanoma skin lesions. However, it is not very suitable for mouth exams due to the strong emission in the ionizing UV spectrum, low irradiance and because its size is not ideal for the size of the mouth and only associated with a transparent magnifying glass that does not filter only the red emissions [ 9]

Based on spectroscopy, disclosure techniques to assist diagnosis have the potential to identify the biochemical and morphological processes of tissues without compromising patient care.

Reasoned on the emission of visible, non-ionizing violet light, with a $405 \mathrm{~nm}$ wavelength with a variation of $10 \mathrm{~nm}$, these techniques serve to scan the oral cavity in search of potentially malignant lesions and choose the most representative area for biopsy. This technique allows us to observe nuances that, in many cases, are imperceptible to the naked eye.

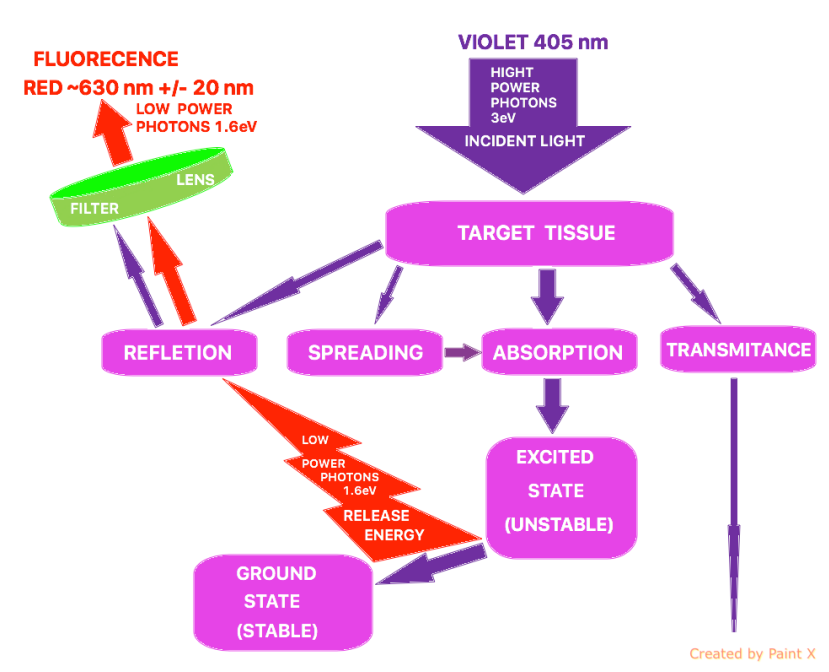

Figure 1. Optical fluorescence scheme infographic.

Results obtained with the first patient, I.A.O., male, white, 55 years old, public servant, resident in Brasilia, history of severe smoking of 40 cigarettes per day, and alcohol consumption in average daily doses.

The patient arrived for a routine visit and complained of a sore on the floor of his mouth, under his tongue, which had appeared a month ago and was not healing. It was examined, with the request that he lift the tip of the tongue, placing it on the roof of the mouth (palate). Adjusting the white illumination of the dental 
chair, the clinician observed a reddish lesion with a more reddish tone than the rest of the surrounding tissues. The shape was spherical, approximately $2 \mathrm{~cm}$ by $1 \mathrm{~cm}$ deep ducts, firmly adhered to the tongue brake and the sublingual caruncle, right in the middle of the two mouth submandibular and sublingual glands.

At that time, the suspicion of an SCC arose. Many thoughts occur to the clinician, such as a graduate professor's speech almost 30 years ago, claiming that some dental surgeons can spend an entire professional life without encountering an oral carcinoma. Besides, another colleague affirmed that it was almost impossible to occur in the group of employees of the agency that assists in finding any case of oral cancer. The equipment was brought to test the idea of simplicity on its use and to verify whether a clinical professional, with no experience in the field of stomatology/pathology, could obtain a greater conviction of being cancer or not.

The clinician took the equipment, wondering if the lack of experience in using it, would be an obstacle, but confident on getting some data that could increase the vague idea that it was a CPB. When turning on the device and looking through the viewfinder, it was possible to notice that the lesion became a little redder, highlighted by the surrounding greenish tissues. Wondering on how to improve the contrast, lights were turned off, because there were many fluorescent lamps directly over the dental chair. When there was only a little indirect light, without the incidence of direct light, the image lighted up as if it were a red beacon over a green sea, causing a particular fright and the absolute certainty that it was strong evidence of being cancer.

This certainty was decisive in the engagement of the professional in convincing the patient to seek urgent care, as he did not have assistance plan, and could not bear the costs of private care. In the public health care where he was attended, basic service is provided, and biopsy would not be possible. So we tried to find out where and who could assist him in any public hospital in Brasilia through SUS (Unified Public Health System). It was found that the Regional Hospital of Asa Norte (HRAN) had this service and a specialist in stomatology. Over the phone, it was possible to make an appointment for a week later, which the clinician went along. At the time of the biopsy, the specialist colleague, without the evidence, told the clinician, in particular, that he suspected, but was not sure, that it was cancer and cautious awaited the biopsy report. The clinician, at no time, had expressed to the patient his conviction that it was cancer, always talking about potentially malignant lesions or how the early diagnosis of a cancerous lesion in the early stages provides a chance of cure of up to $100 \%$.

The biopsy result came approximately 15 days after its extraction, with confirmation of the diagnostic hypothesis of SCC, which presented a fragment of $0.6 \mathrm{x}$ $0.5 \times 0.1 \mathrm{~cm}$, structure altered by infiltrative neoplasm, a squamous cell carcinoma (SCC) well-differentiated, front of expansive invasion, with the absence of vascular and neural invasion.

Within the Biopsy Report came the certainty that it was a SCC. Although the HRAN could have performed the surgical removal of the lesion, and the patient underwent pelvic glossectomy to excise the lesion with a safety margin, in order to remove much of the oral floor, as a consequence, causing bone exposure, the patient chose to be operated by a Surgeon who was also a relative from a nearby city, which is $200 \mathrm{~km}$ from Brasília and, therefore, the clinician was unable to go along.

Upon anatomopathological examination, a final 2.5 $\mathrm{cm}$ lesion with $1 \mathrm{~mm}$ depth and all free margins was detected.

He returned with the total removal of the lesion in situ, with free margins, and it was found that he had no metastases, so chemotherapy or radiotherapy was not indicated. After one month, the clinician followed the postoperative period, when he was already in the healing phase due to the second intention, exposed mandibular bone, with complete healing coming in four months. He was $100 \%$ cured of cancer, with a slight sequel of ankylosis on his tongue, difficulty pronouncing some words, and slight dysphagia.

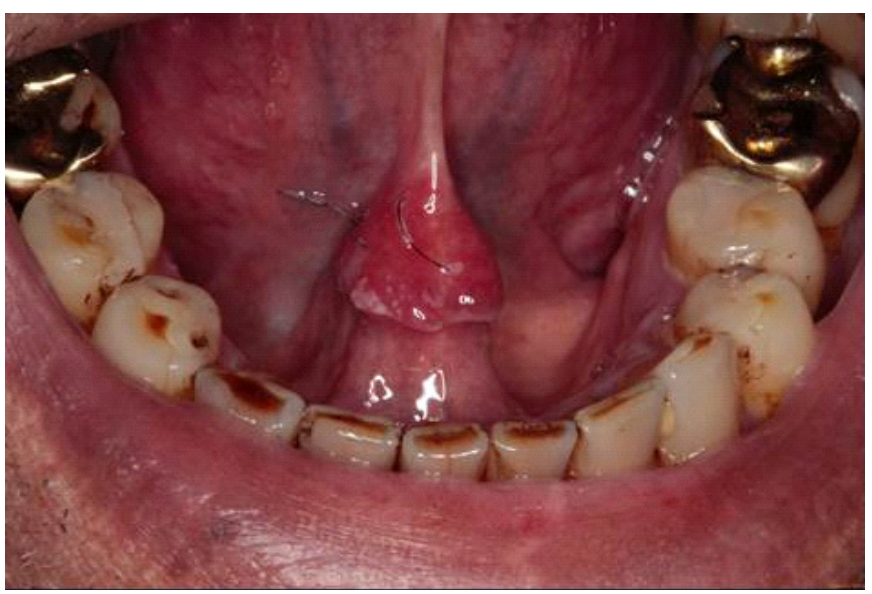

Figure 2. Sublingual caruncle fifteen days after biopsy and suture present. 


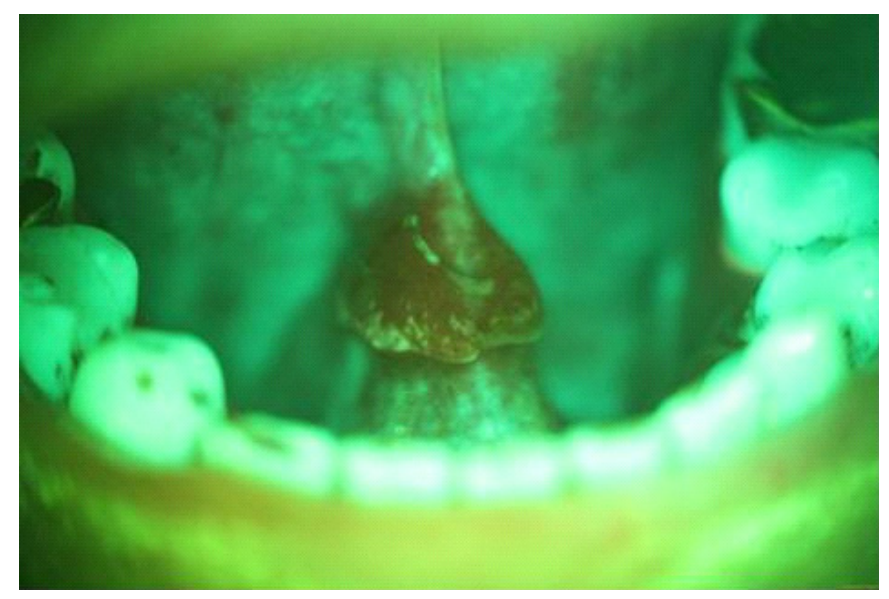

Figure 3. Sublingual caruncle fifteen days after biopsy and photo evidencing at the injury site.

With the therapeutic proposal to aid in bone healing, photodynamic therapy, also called Photodynamic Therapy (PDT), was used, in which the application of methylene blue Chimiolux ${ }^{\circledR}$ is necessary, following a waiting time for irradiation (Pre Irradiation Time, PIT) of 3 minutes, followed by the application of the $660 \mathrm{~nm}$ red resonant LASER light, power $100 \mathrm{~mW}$, dose of 9 joules, with a total of 90 seconds (figure 4). Thus, the exposed area was closed and, after total healing, he had a sequel of ankyloglossia and speech difficulties. The PDT therapy technique helped in the microbial reduction of the exposed bone area, resulting in faster healing of the open tissue [15]. Currently, the patient is under periodic control, including medical monitoring.

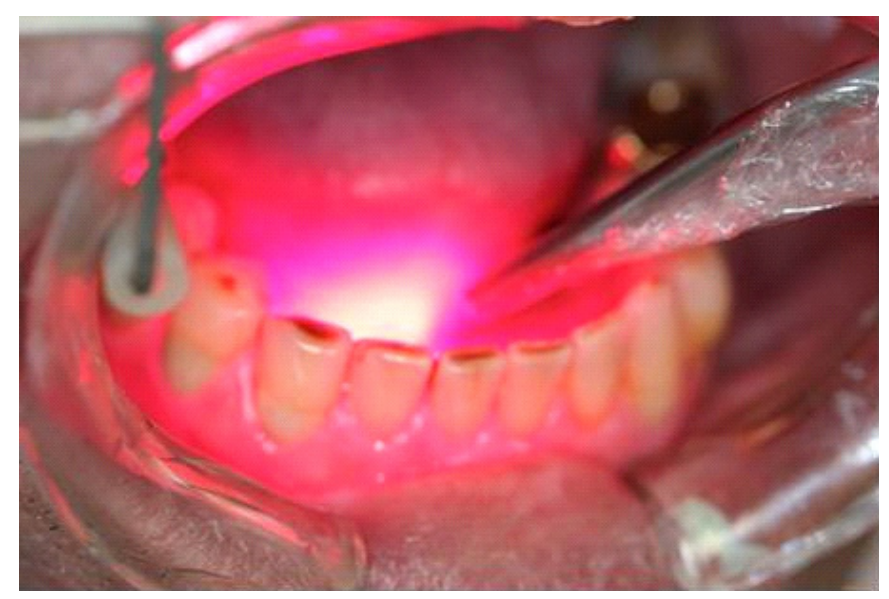

Figure 4. Image showing the application of low intensity LASER, helping with bone healing.
Concerning the case presented here, we conclude that ankyloglossia, a reported sequel, is of little relevance given the clinical condition addressed. Considering that the patient has a malignant lesion discovered early and, if not treated and eliminated, would have more severe complications for him and his family members.

Results obtained with the second patient, T.G.C., female, 58 years old, with no history of smoking and alcohol consumption or any other harmful habit, residing in Luziânia / GO. In the anamnesis, the patient reported that she did not feel pain in the oral cavity. The search for the dental surgeon had been suggested by her son, recently graduated in dentistry, a student in the oralmaxillofacial course, on suspicion of a malignant lesion in lateral border of tongue. She reported that a year earlier she had had a biopsy of two irregular fragments, an unidentified topography, sizes of $0.5 \times 0.4 \times 0.1 \mathrm{~cm}$ with a report of absence of signs of malignancy. This light lymphocytic infiltration could correspond to squamous cell papilloma, so no treatment was given, although the patient complained that the lesion did not regress. On clinical examination, all pathognomonic signs of a latestage intraoral CPB were found. Some manifestations such as a painless, exophytic, nodular lesion, raised, hardened edges, rough and irregular surface, erythematous, discrete superficial keratinization, infarcted lymph nodes, and irregular, and superficial ulceration. When the clinician observed with the optical fluorescence photoevidenciation device, the clear diagnostic hypothesis of possible CPB was raised (figure 5).

The patient was referred for a new biopsy to confirm the clinical case and was diagnosed with invasive

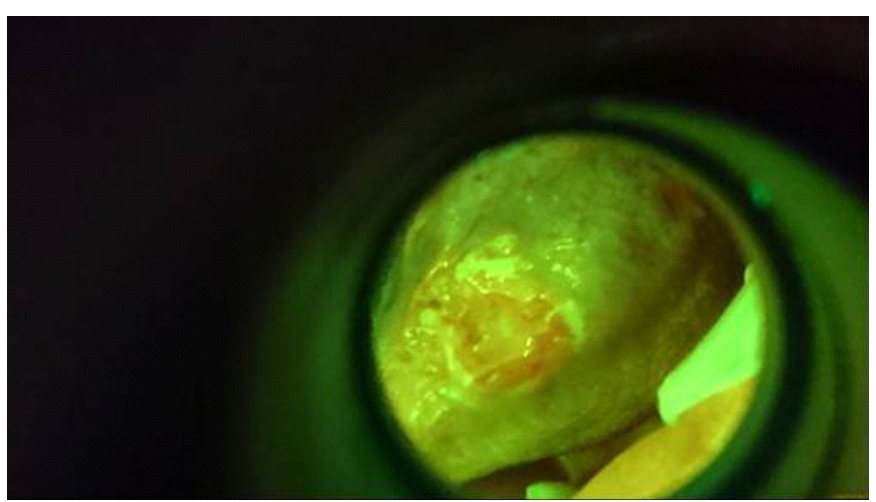

Figure 5. Image of the photo evidencing of the hypothesis lesion diagnosed as possibly SCC in the dental clinic. 
CPB, grade II (2) of ICD-0 aplasia. She was directed to the head and neck surgeon to remove the right side of the tongue and chemotherapy and or radiation therapy. The biopsy report after hemiglossectomy was: tumor size $2.1 \times 0.8 \times 1.0 \mathrm{~cm}$ and $8.3 \times 4.8 \times 1.6$, ulcerated, confirming an invasive CPB diagnosis, free surgical margins and a lower margin of $1.0 \mathrm{~cm}$, grade II (2) of differentiation, without vascular invasion, with perineural invasion, with one of the ten cervical lymph nodes removed, it presented metastasis without extranodal extension, neoplasia-free salivary gland. The patient metastasized months later due to the late diagnosis of cancer and, as a consequence, went through more chemotherapy and radiotherapy sessions.

Due to this, she presented grade IV oral mucositis, according to the World Health Organization (WHO) classification, requiring the use of low-intensity LASER with photodynamic therapy (PDT). This technique relieves pain throughout the mouth [10].

In cases of OM, low-intensity LASER is used as a therapeutic proposal for pain relief in the region and healing of the ulcer, as shown in figure 6 .

Nine months after the late discovery of CPB and intense chemotherapy, the patient died.

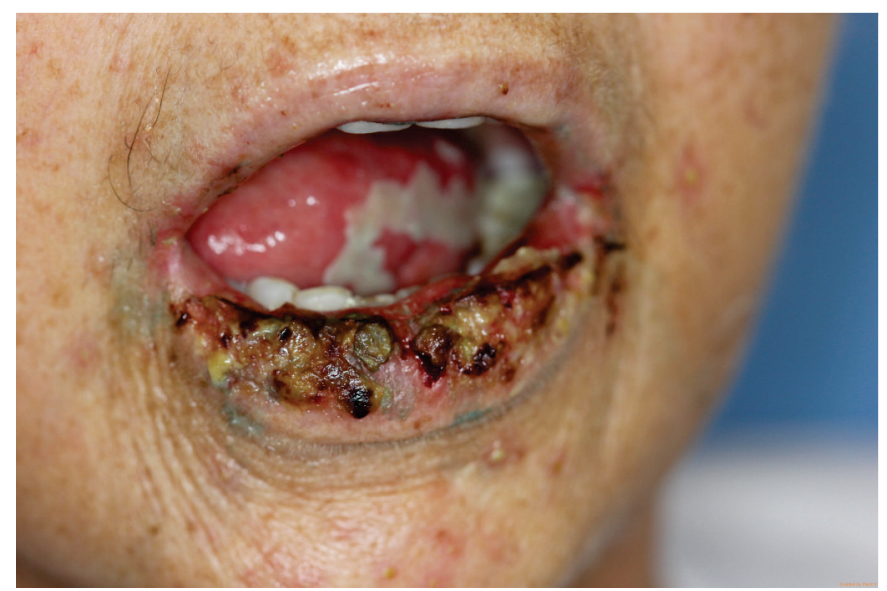

Figure 6. Oral mucositis and the application of PDT to perform photodynamic therapy with low-intensity LASER.

\section{DISCUSSION}

Based on epidemiological data, it is possible to state that oral cancer is a disease of high incidence in the world and that it is still considered a severe public health problem. In most oral cancer cases, the diagnosis is made late because of the difficulty of assessing initial lesions since they are usually asymptomatic and are not perceived. This difficulty occurs due to a lack of knowledge of pathology, deficiency in the search for medical care by the individuals, poor access, and the precarious quality of health care.

The literature recommends the classification of WHO oral mucositis (OM) in four gradual degrees of intensity. Clinically, it consists of mucosal inflammation with the presence of erythema and edema, progressing to the development of ulcers, and the formation of a pseudomembrane. Pain, burning, and discomfort are significant and accentuated with chewing, verbal communication, and oral hygiene. The most affected areas are the mouse floor, lateral border of the tongue, lingual belly, cheek mucosa, and soft palate [10].

$\mathrm{OM}$ is a debilitating complication in the usual oral cavity in patients undergoing chemotherapy, and radiotherapy. Debilitation is a consequence of the treatment and the potentially malignant lesions, which causes a considerable impact on these patients' quality of life, especially in the financial, psychological and social spheres [11].

As already mentioned, oral cancer is commonly diagnosed in an advanced stage of the disease, severely damaging its clinical, psychological, and social condition. Therefore, based on clinical and literary data, it is observed that early detection is of significant importance in the quality of life of patients and their families.

The dentist's performance is essential in the patient's early diagnosis since he is a layman and has difficulty performing a self-assessment. In the educational process, future professionals have training in the subjects of oral pathologies, stomatology, and fluorescence methods to seek the early detection of oral cancer [12] soon.

Professional dental surgeons should go through continuing education programs so that they soon identify PML or SCC and use supporting techniques to accelerate diagnosis for early detection, especially for smokers, aiming at providing more remarkable survival [12].

Before a biopsy, in some cases, exfoliative cytology can be performed with a superficial scraping, analysis under a microscope. If any dysplasia occurs, then surgical removal of a representative part of the lesion should be performed. This routine is considered the gold standard for accelerating the biopsy and rapid arrival at diagnosis [12]. 
The biopsy can replace the incisional biopsy with a thick needle (Core needle biopsy - CNB). This CNB is accurate, is not misleading for diagnosing soft tissue sarcoma, avoids complications of open biopsy, and allows the planning of surgery or neo chemotherapy -adjuvant when combined with appropriate imaging exams [13].

The Oral cavity is composed of stratified squamous epithelium that is basically subdivided into three types of epithelium:

1.Coating mucosa, non-keratinized. Eg Lips, cheek mucosa (cheeks), soft palate, free gum, lingual belly, and buccal floor.

2.Parakeratinized Masticatory Mucosa, Partial Keratinization. Ex. On the back and the margin of the tongue.

3.Masticatory mucosa, orthokeratinized, total keratinization of the last horny layer. Eg Gingiva inserted marginally fixed around the teeth and hard palate [14].

Oral cancer can affect the entire oral cavity, tongue, lips and oropharynx. Inside the mouth, gums, mucous jaws (cheeks), hard palate (roof of the mouth), tongue (especially the edges), as well as the region of the floor of the lingual should be observed.

Some oral lesions are benign, do not invade other tissues or spread to other organs, but need to be treated or removed.

The mouth has numerous tissues and, therefore, can be affected by different types of cancer. Each case's treatment depends on the cells involved, infiltration and staging, facts that define the prognosis and the patient's chances of survival.

Potentially malignant lesions (PML) have a harmless onset but can become malignant over a long time [15].

A PMS like leukoplakia is a whitish area that is usually benign, rarely develops into cancer, but in $25 \%$ of cases, it can develop into cancer over a decade, if left untreated and predisposing agents as alcoholism and smoking disappear [15].

PML, like erythroplasia, is a reddish lesion, slightly elevated, usually asymptomatic, which does not come out in exfoliative scraping. PML is generally more worrying, and in $90 \%$ of cases, there is already a histological picture of dysplasia (mild or moderate), carcinoma in situ or invasive carcinoma. Prevalence ranging from 0.02 to $0.83 \%$, which may be underestimated due to the difficulty of identifying it [15].
The variant of Verrucous Carcinoma (Ackerman LV.Verrucous carcinoma of the oral cavity. Surgery. 1948; 23: $670-8$.) In the order of $5 \%$ of oral occurrences, it is rare, has characteristics of slow growth, more expansive than infiltrative, low degree of dysplasia, with no tendency to produce metastases. Therefore, it is considered by many to have "benign" characteristics. The treatment of choice is surgical excision, which presents a risk of recurrences, even in its total removal [16].

Staging is the classification of the extent, degree of tumor dysplasia, and whether or not there was the involvement of the lymph nodes or other organs (metastases). For this, a combination of letters and numbers is used: $T$ for tumor, $\mathrm{N}$ for nodules (or lymph nodes), and $M$ for metastasis. The second character is an $X$ for admission and undiagnosed. It is then numeric for tumors (T) ranging from 1 to 4 to determine the size, degree of dysplasia and invasion of adjacent structures. The lymph nodes ( $\mathrm{N}$ ) accompanied by a number from 0 to 4, starting without adenopathy, unilateral, bilateral adenopathy, and the size of the nodules. Metastasis (M) plus numeric 0 for no metastasis and 1 for distant metastasis [17].

Based on the first clinical case presented here, it is noted that the early diagnosis of cancer is fundamental and necessary to avoid future problems, such as emotional distress of those involving financial costs, loss of quality of life, and the social relationships of these individuals.

\section{CONCLUSION}

Optical fluorescence has a great potential to assist non-specialist professionals in early diagnosis of oral cancer. This technique makes it possible to reduce the death rates of this late detected carcinoma in Brazil and allow extending post-diagnostic survival, reducing costs, hence its great social relevance.

\section{REFERENCES}

1. Brasil. Instituto Nacional de Câncer José Alencar Gomes da Silva. Coordenação de Prevenção e Vigilância. Estimativa 2018: incidência de câncer no Brasil [citado 2018 Jul 10]. Disponível em: <http://www1.inca.gov.br/rbc/n_64/v01/ pdf/15-resenha-estimativa-2018-incidencia-de-cancer-nobrasil.pdf>.

2. Brasil. Ministério da Saúde. Ministério da Saúde chama atenção para a Semana Nacional de Prevenção do Câncer 
Bucal [citado 2018 Nov 5]. Disponível em: <https://www. saude.gov.br/noticias/agencia-saude/44603-ministerioda-saude-chama-atencao-para-a-semana-nacional-deprevencao-do-cancer-bucal>.

3. Ferlay J, Steliarova-Foucher E, Lortet-Tieulent J, Rosso S, Coebergh JWW, Comber $\mathrm{H}$, et al. Cancer incidence and mortality patterns in Europe: Estimates for 40 countries in 2012. Eur J Cancer. 2013;49(6):1374-1403. http://dx.doi. org/10.1016/j.ejca.2012.12.027

4. Brasil. Instituto Nacional de Câncer José Alencar Gomes da Silva. Coordenação de Prevenção e Vigilância. Estimativa 2012: incidência de câncer no Brasil [citado 2018 Jul 10]. Disponível em: <https://www.inca.gov.br/sites/ufu.sti.inca. local/files//media/document/informativo-vigilancia-docancer-n2-2012_0.pdf>.

5. Vidal $A K L$, Caldas Júnior $A F$, Mello RJV, Brandão VRA, Rocha GI, Taromaru E. HPV detection in oral carcinomas. J Bras Patol Med Lab. 2004;40(1):21-26. http://dx.doi.org/10.1590/ S1676-24442004000100007

6. Carvalho MB, Lenzi J, Lehn CN, Fava AS, Amar A, Kanda JL. et al. Características clínico: epidemiológicas do carcinoma epidermóide de cavidade oral no sexo feminino. Rev Assoc Med Bras. 2001;47(3):208-14. http://dx.doi.org/10.1590/ S0104-42302001000300032

7. Dedivitis RA, França CM, Mafra ACB, Guimarães FT, Guimarães AV. Características clínico-epidemiológicas no carcinoma espinocelular de boca e orofaringe. Rev Bras Otorrinolaringol. 2004;70(1):35-40. http://dx.doi.org/10.1590/ S0034-72992004000100006

8. Calandro TLL, Werneck JT, Gonçalves SS, Júnior AS, Dias EP. Utilização do teste com o azul de toluidina como método auxiliar no diagnóstico de lesões orais. Rev Bras Odontol. 2011;68(2):96-9.

9. Veasey JV, Miguel BAF, Bedrikow RB. Lâmpada de Wood na dermatologia: aplicações na prática diária. Surg Cosmet
Dermatol. (Impr.) 2017;9(4):328-330. http://dx.doi.org/10.5935/ scd1984-8773.201794964

10. Sonis ST. A Biological approach to mucositis. J Supp Oncol. 2004;2(1):21-32.

11. Antunes HS, Schluckebier LF, Herchenhorn D, Small IA, Araújo CMM, Viégas CMP, et al. Cost-effectiveness of low-level laser therapy (LLLT) in head and neck cancer patients receiving concurrent chemoradiation. Oral Oncology. 2016;52:85-90. http://dx.doi.org/10.1016/j.oraloncology.2015.10.022

12. Silverman S, Rankin KV. Oral and pharyngeal cancer control through continuing education. J Canc Educ. 2010; 25:277-278. http://dx.doi.org/10.1007/s13187-010-0044-7

13. Ray-Coquard I, Ranchère-Vince $D$, Thiesse $P$, Ghesquières $H$, Biron P, Sunyach MP, et al. Evaluation of core needle biopsy as a substitute to open biopsy in the diagnosis of soft-tissue masses. Eur J Cancer. 2003;39(14):2021-5. http://dx.doi. org/10.1016/S0959-8049(03)00430-1

14. Balogh MB, Fehrenbach MJ. Anatomia, histologia e embriologia dos dentes e estruturas orofaciais. $3^{\text {a }}$ ed. Rio de Janeiro: Elsevier; 2012.

15. Oliveira RM, Abdo EN. Eritroplasia oral: uma revisão de literatura. Belo Horizonte: Universidade Federal de Minas Gerais; 2011.

16. Zanini M, Wulkan C, Paschoal FM, Maciel MHM, Machado Filho CDA. Carcinoma verrucoso: uma variante clínico-histopatológica do carcinoma espinocelular. An Bras Dermatol. 2004;79(5):619-621.

17. Singletary SE, Allred C, Ashley P, Bassett LW, Berry D, Bland KI, et al. Revision of the American Joint Committee on Cancer staging system for breast cancer. J Clin Oncol. 2002;20(17):3628-36. http://dx.doi.org/10.1200/JCO.2002.02.026

Received on: 21/10/2019

Final version resubmitted on: 28/2/2020

Approved on: 28/8/2020 